\title{
Memahami al-Qur'an dengan Kearifan Lokal: Nuansa Budaya Sunda dalam Tafsir al-Qur'an berbahasa Sunda
}

\author{
Jajang A Rohmana ${ }^{1}$
}

\begin{abstract}
The local interpretation of the Qur'an cannot be ignored in the discourse of Qur'anic studies in Indonesia. Its significance lays not only in the continuity of Islamic tradition networks, but also in the creativity of linguistic expression and its content of local wisdom relevant with the need of society. This study tries to shed light on the Sundanese cultural nuance in Sundanese Qur'anic interpretation. There are at least three elements which indicate Sundanese cultural nuance which becomes the characteristic of local reception of the Qur'an in Sundanese Qur'anic interpretation: the use of speech level, traditional expression and the metaphore of Sundanese nature. These three elements can be used as the first categorization to classify Sundanese Qur'anic interpretation as Sundanese.
\end{abstract}

\begin{abstract}
Abstrak
Tafsir lokal Al-Qur'an tidak bisa diabaikan dalam diskursus kajian Al-Qur'an di Nusantara. Signifikansinya tidak hanya terletak pada kesinambungan jaringan tradisi keilmuan Islam Nusantara, tetapi juga dalam kreatifitas ekspresi bahasa dan kandungan kearifan budaya lokal yang sesuai dengan kebutuhan masyarakat. Kajian ini berusaha memberikan sedikit gambaran tentang nuansa budaya Sunda dalam tafsir Sunda. Sedikitnya terdapat tiga hal yang menunjukkan nuansa budaya Sunda yang menjadi karakter resepsi lokal Al-Qur'an dalam tafsir Sunda: penggunaan tingkatan bahasa (undak usuk basa, speech levels), ungkapan tradisional dan metafor
\end{abstract}

${ }^{1}$ Dosen UIN Sunan Gunung Djati Bandung E-mail: jajang_abata@yahoo.co.id. Draf Makalah dipresentasikan pada Third Annual QUHAS Conference, pada 24 Desember 2013 di UIN Syarif Hidayatullah Jakarta. 
alam Sunda. Ketiganya kiranya menjadi pertimbangan awal sejauh mana sebuah tafsir Sunda bisa dikatakan betul-betul nyunda atau bercitarasa Sunda.

Keywords: tafsir Sunda, bahasa, budaya Sunda, kearifan lokal

\section{A. Pendahuluan}

Tak bisa dipungkiri, manusia merupakan makhluk berbudaya. Dengan daya cipta, rasa, dan karsa, manusia memproduksi kebudayaannya. ${ }^{2}$ Ia lahir dan hidup dalam pluralitas ruang budaya yang diproduksinya agar saling kenalmengenal, saling menghargai eksistensi masing-masing (QS. Al-Hujurāât [49]: 13). Dengan demikian, pluralitas budaya, baik berupa eksistensi kelompokkelompok berbeda secara etnis, ras, bahasa, bahkan agama harus disadari dan diterima. Karena penerimaan akan pluralitas budaya ini, kaum Muslim-meski menganggap kesatuan umat Islam (ummah wäḥidah)sebagai identitas bersama-umumnya memegang erat identitas lainnya seperti kesukuan atau etnis. $^{3}$

Di tatar Sunda, kaum Muslim menerima identitas keislaman dan kesundaan sebagai dua eksistensi yang saling mengisi dan beradaptasi. Islam yang semula berasal dari jazirah Arab sudah melebur dan merasuk (awor, nyosok jero) ke dalam identitas Sunda. Sunda Ngislam, Islam Nyunda. ${ }^{4}$ Sulit kiranya memisahkan keduanya. Islam diadaptasikan ke dalam wujud kehidupan keagamaan yang bernuansa budaya Sunda. Sebaliknya aktifitas budaya orang Sunda banyak dibentuk dan dipengaruhi pula oleh nilai-nilai ajaran Islam. ${ }^{5}$

${ }^{2}$ Koentjaraningrat, Pengantar Ilmu Antropologi (Jakarta: Rineka Cipta, 1990), cet. ke-8, 193; Koentjaraningrat, Kebudayaan, Mentalitas dan Pembangunan (Jakarta: Gramedia Pustaka Utama, 2004), 5-6.

3 Irene Schneider "Legal and Ethno-Religious", dalam Richard C. Martin, Encyclopaedia of Islam and the Muslim World Vol. 2, (New York: Macmillan, 2004), 533.

4 Oyon OS, "Islam Nyunda \& Sunda Ngislam," dalam Wahyu Wibisana dkk., Salumar Sastra (Bandung: Geger Sunten, 1997), cet. ke-2, 175-176.

${ }^{5}$ Orang Sunda adalah mereka yang mengaku dirinya dan diakui oleh orang lain sebagai orang Sunda. Orang lain itu berupa baik orang Sunda sendiri maupun orang yang bukan Sunda. Suwarsih Warnaen dkk., Pandangan Hidup Orang Sunda Seperti Tercermin dalam Tradisi Lisan dan Sastra Sunda (Bandung: Bagian Proyek Penelitian dan Pengkajian Kebudayaan Sunda (Sundanologi) Dirjen Kebudayaan Depdikbud Bandung, 1987), 1 . 
Salah satunya tampak dalam tradisi intelektual Islam seperti vernakularisasi Al-Qur'an melalui terjemah atau tafsir berbahasa Sunda. ${ }^{6}$ Ia tidak saja menjelaskan makna dibalik ayat, tetapi juga menyelaraskan konsep dan nilai ajarannya ke dalam alam pikiran budayanya. Terjadi persentuhan konsep dan nilai keislaman untuk didialogkan dan diselaraskan dengan kearifan pandangan hidupnya. ${ }^{7}$ Vernakularisasi kitab suci menjadi sangat diwarnai oleh alam pikiran budaya orang Sunda. Inilah yang dimaksudkan Haji Hasan Mustapa (1852-1930) sebagai baheula ku basa Sunda, ayeuna ku basa Arab, kaula nyundakeun Arab nguyang ka Arab, ngarabkeun Sunda tina basa Arab. ${ }^{8}$

Kajian ini membahas pada upaya orang Sunda dalam meresepsi kitab suci ke dalam tafsir berbahasa Sunda. Bagaimana orang Sunda, dalam bahasa Zimmer, berupaya mendomestikasi dan menjembatani jarak antara bahasa AlQur'an dan bahasa lokal. ${ }^{9}$ Karenanya pembahasan difokuskan pada upaya penafsir dalam memasukkan nuansa budaya Sunda ke dalam penafsiran. Nuansa budaya Sunda berkaitan erat dengan ragam nilai kearifan lokal yang pada gilirannya turut membentuk horison penafsiran. ${ }^{10}$ Penggunaan nuansa budaya Sunda menjadi indikator penting sejauh mana sebuah tafsir betul-betul nyunda atau bercitarasa Sunda. Sebuah kajian awal tentang model kreatifitas pendekatan tafsir kitab suci bernuansa etnis lokal Nusantara yang berusaha mengakomodasi kekayaan latar budayanya.

${ }^{6}$ A.H. Johns, "She Desired Him and He Desired Her" (Qur'an 12:24): 'Abd alRa'ûf's Treatment of An Episode of the Joseph Story in Tarjumān al-Mustafid," Archipel. Vol. 57, 1999: 109; Farid F. Saenong, "Vernacularization of the Qur'an: Tantangan dan Prospek Tafsir Al-Qur'an di Indonesia”, Interview dengan Prof. A.H. Johns, Jurnal Studi Al-Qur'an, Vol. 1, No. 3, 2006, 579.

7 Tentang dialektika Al-Qur'an dan budaya lokal Jawa, lihat Imam Muhsin, “Tafsir Al-Qur'an dan Budaya Lokal,” Disertasi UIN Sunan Kalijaga, 2008.

${ }^{8}$ Haji Hasan Mustapa, Qur'anul Adhimi Adji Wiwitan Qur'an Sutji, kenging ngumpulkeun Wangsaatmadja, Bandung 7 Juli 1920, 3; Ajip Rosidi, Haji Hasan Mustapa jeung Karya-karyana (Bandung: Pustaka, 1989), 394. Artinya: Dahulu (beragama) dengan bahasa Sunda, sekarang dengan bahasa Arab. Saya menyundakan Arab (menyelaraskan Sunda dengan Islam) datang ke Arab, mengarabkan (mengislamkan) Sunda dengan bahasa Arab.

9 Benjamin G. Zimmer, "Al-'Arabiyyah and Basa Sunda: Ideologies of Translation and Interpretation among the Muslims of West Java”, Studia Islamika, 7 (3): 2000,31

${ }^{10}$ Kearifan lokal (local genius, local wisdom) mengandung arti kemampuan dan kreatifitas kebudayaan setempat dalam menghadapi pengaruh kebudayaan asing. Lihat Ajip Rosidi, Kearifan Lokal dalam Perspektif Budaya Sunda (Bandung: Kiblat, 2011), 29-30. 


\section{B. Ragam Tafsir Berbahasa Sunda}

Inti penggalian kehidupan keagamaan dan budaya kaum Muslim di Asia Tenggara tidak bisa dilepaskan dari proses vernakularisasi. Ia merupakan upaya pembahasalokalan ajaran Islam (Al-Qur'an) yang diterjemah dan ditulis ke dalam bahasa dan aksara lokal (jawi, pégon) jauh sebelum abad ke-18. ${ }^{11}$ Ini dilakukan melalui penerjemahan lisan kutipan-kutipan pendek Al-Qur'an, pengadaptasian tulisan Arab dalam terjemah antar baris atau catatan pinggir (sebagian atau keseluruhan teks), hingga penulisan literatur berbahasa Arab oleh penulis lokal yang pada gilirannya diterjemahkan ke dalam bahasa lokal (Arabisasi bahasa lokal). ${ }^{12}$

Vernakularisasi Al-Qur'an baik lisan maupun tulisan berkembang di hampir semua kawasan di Nusantara. Upaya ini tidak berarti menafikan tradisi pengkajian Al-Qur'an Nusantara yang ditulis dalam bahasa Arab. ${ }^{13}$ Selain lokalitas bahasa seperti Jawa, Sunda, Bugis dan lainnya, kajian lokal Al-Qur'an juga melahirkan kreatifitas ragam aksara, seperti jawi (Melayu-Jawi) dan pégon untuk Jawa atau Sunda. Selain itu digunakan pula aksara lokal seperti cacarakan (Jawa), kaganga (Sunda) dan lontara (Bugis), sebelum kemudian digeser oleh aksara Arab jawi atau pegon dan akhirnya roman/latin sejak era kolonial.

Di tatar Sunda, secara umum, belum diketahui bagaimana penerjemahan dan penafsiran Al-Qur'an awal ke dalam bahasa Sunda. Namun, vernakularisasi awal setidaknya tampak pada beberapa kosakata Arab yang mempengaruhi bahasa Sunda seperti pada naskah Carita Parahiyangan dan Sri Ajnyana dari abad ke-16. ${ }^{14}$ Selain itu, dari studi filologi naskah-naskah Sunda abad ke-18, diketahui bahwa dibanding kajian fiqih, hanya terdapat sedikit naskah tentang kajian Al-Qur'an. ${ }^{15}$ Ini kiranya menunjukkan bahwa Islamisasi hampir selalu

${ }^{11}$ Ervan Nurtawab, Tafsir Al-Qur'an Nusantara Tempo Doeloe (Jakarta: Ushul Press, 2009), 147.

12 A.H. Johns, "Penerjemahan" Bahasa Arab ke dalam Bahasa Melayu: Sebuah Renungan, dalam Henri Chambert-Loir (ed.), Sadur Sejarah Terjemahan di Indonesia dan Malaysia, Jakarta: KPG, 2009, 51-53.

${ }_{13}$ Misalnya Tafsir Marah Labid karya Sayyid Ulama Hijaz Al-Nawawi AlBantani (1813-1879) dan sejumlah tafsir bahasa Arab yang ditulis ulama pesantren di Jawa. Lihat Didin Hafiduddin, "Tafsir al-Munir Karya Imam Muhammad Nawawi Tanara" dalam Ahmad Rifa'i Hasan (ed.), Warisan Intelektual Islam Indonesia (Bandung: Mizan, 1992), 39-56.

14 Ajip Rosidi (ed.), Ensiklopedi Sunda, Alam, Manusia dan Budaya (Jakarta: Pustaka Jaya, 2000), 620; J. Noorduyn dan A. Teeuw, Tiga Pesona Sunda Kuna, terj. Hawe Setiawan (Jakarta: Pustaka Jaya, 2009), 168.

15 Tercatat beberapa kajian tentang naskah-naskah Sunda telah dilakukan, di antaranya yang dilakukan Edi S. Ekajati dalam Naskah Sunda(1983); Viviane Sukanda- 
diawali berbagai pembahasan praktik keagamaan (fiqih) dibanding aspek literasi dan intelektual. Ini juga menunjukkan bahwa kajian Al-Qur'an sudah berkembang setidaknya pada abad ke-18 seiring dengan menguatnya Islam pasca jatuhnya Kerajaan Sunda pada $1579 .{ }^{16}$

Dibanding terjemah Al-Qur'an, tafsir berbahasa Sunda kiranya berkembang lebih belakangan. Beragam aksara, dialek bahasa, metode dan latar ideologis kiranya menghiasi perkembangan tafsir Sunda. Dibanding tafsir lokal lain di Nusantara, tafsir Sunda kiranya cukup banyak dengan lebih dari belasan tafsir yang pernah dipublikasikan. ${ }^{17}$

Dari sisi aksara, beberapa tafsir Sunda awal (pra-kemerdekaan) menggunakan aksara pegon, misalnya tampak pada naskah Qur'anul Adhimi (1921-1922) karya Haji Hasan Mustapa (1852-1930) sebelum kemudian ditranskripsi ke dalam stensilan beraksara latin/roman. ${ }^{18}$ Sejumlah tafsir Sunda karya KH. Ahmad Sanusi (1888-1950) juga menggunakan aksara pegon dan dipublikasikan dengan cetak litograf. ${ }^{19}$ Beberapa publikasi terjemah dari tafsir seperti Al-Jalalayn beraksara pegon hingga saat ini juga masih beredar di kalangan pesantren Sunda, misalnya dilakukan oleh KH. Ahmad Makki dan

Tessier dari EFEO dalam Naskah Yang Belum Diinventarisasikan di Jawa Barat (1987); A. Cholid Sodrie dkk. dalam Laporan Penelitian Naskah Kuno Jawa Barat (1986, 1987); Ajip Rosidi khusus mengenai Haji Hasan Mustapa jeung Karya-karyana (Bandung: Pustaka, 1989); dan Edi S. Ekadjati dan Undang A. Darsa dalam Katalog Induk NaskahNaskah Nusantara Jilid 5A: Jawa Barat; Koleksi Lima Lembaga (Jakarta: YOI dan EFEO, 1999).

16 Edi S. Ekadjati, "Sejarah Masuknya Islam ke Tatar Sunda dan Perkembangannya," dalam Perhimpunan KB PII, Ngamumule Budaya Sunda Nanjeurkeun Komara Agama (Bandung: Perhimpunan KB PII, 2006), 28-29.

${ }^{17}$ Jajang A Rohmana, "Kajian Al-Qur'an di Tatar Sunda: Sebuah Penelusuran Awal," Jurnal Suhuf, Vol. 6, No. 1, 2013, 197-224.

${ }^{18}$ Haji Hasan Mustapa, Qur'anul Adhimi Adji Wiwitan Qur'an Sutji, kenging ngumpulkeun Wangsaatmadja, Bandung 7 Juli 1920; Haji Hasan Mustapa, Petikan Qoer'an Katoet Adab Padikana, diurus djeung diatur ku Comite Mendakna (Bandung: Droek Boehron Bd., 1937); Ajip Rosidi, Hasan Mustapa jeung Karya-karyana, 389-433.

19 Ahmad Sanusi, Malja' al-Ṭâlibīin fì Tafsìr Kalām Rabb al-'Alamīn, Pangadjaran Basa Soenda (Batavia Centrum, Kantor Cetak Al-Ittihad, 1931/1349 H.); Ahmad Sanusi, Rawḍt al-'Irfān fí Ma'rifat al-Qur'ān (Sukabumi: Pesantrén Gunung Puyuh, t.th.); Ahmad Sanusi, Tamsjijjatoel-Moeslimien Fie Tafsieri Kalami Rabbil'Alamien (Sukabumi: Druk Al-Ittihad, 1931); Tentang Sanusi dan tafsirnya, lihat Mohammad Iskandar, Para Pengemban Amanah, Pergulatan Pemikiran Kiai dan Ulama di Jawa Barat 1900-1950 (Yogyakarta: Mata Bangsa, 2001); Fadlil Munawar Manshur, "Rawḍat al-'Irfān fì Ma'rifat al-Qur'ān Karya Kiai Haji Ahmad Sanusi: Analisis Semiotik dan Resepsi, ”Tesis PPs UGM, 1992. 
Abdullah bin Hasan Caringin Sukabumi. ${ }^{20}$ Di luar tafsir tersebut, tafsir Sunda umumnya menggunakan aksara latin/roman (baik ejaan lama ataupun EYD), seperti Tafsir Surat Al-Baqoroh berbentuk dangding/guguritan karya Bupati Bandung, R.A.A. Wiranatakusumah V (1888-1965) dibantu oleh R.A.A. Soeriamihardja, mantan bupati Purwakarta; ${ }^{21}$ Tafsir Al-Foerqan bahasa Sunda (1929) karya A. Hassan diterjemahkan oleh Djoeragan Mh. Anwar Sanuci dan Djoeragan Mh. Djoenaédi dari Garut; ${ }^{22}$ Nurul-Bajan (1960) karya Mhd. Romli (1889-1981) danH.N.S. Midjaja (1903-1975); ${ }^{23}$ Alkitabul Mubin (1974) karya Mhd. Romli, ${ }^{24}$ Tafsir Sunda ProyekPemprov dan Kanwil Depag Jawa Barat (1978), ${ }^{25}$ Ayat Suci Lenyepaneun karya Moh. E. Hasim (1916-2009), ${ }^{26}$ dan tafsir Sunda lain sesudahnya seperti $A$ l-Razi (2010) karya Uu Suhendar. ${ }^{27}$

Selain aksara, kiranya menarik bila kita membandingkan keragaman bahasa Sunda dalam tafsir. Tafsir Sunda awal jauh sebelum kemerdekaan cenderung menggunakan bahasa Sunda yang relatif "bebas" dan tidak terlalu menekankan pada tingkatan bahasa (speech levels, undak usuk basa). Ini misalnya tampak pada Qur'anul Adhimi karya Mustapa dan sejumlah tafsir Sunda karya Sanusi. Kata aing (Ind.: aku [kasar])misalnya, masih secara leluasa digunakan. Kesan berbeda dirasakan bila membaca Nurul-Bajan, Alkitabul Mubin, Ayat Suci Lenyepaneun, Tafsir Sunda Proyek, dan Al-Razi yang lahir pasca kemerdekaan. Umumnya bahasa Sunda yang digunakan cenderung menekankan aspek kehalusan bahasa atau bahasa hormat. Perbedaan ini kiranya

${ }^{20}$ Ahmad Makki bin KH. Abdullah Mahfudz, Tarjamah Tafsìr Al-Qur'ān A1'Azīim li Jalāluddìn Al-Suyūtīi wa Jalāluddin Al-Mahalli, Jilid 1, (Sukabumi: Percetakan Al-Salafiyah, tt.); Muhammad 'Abdullah bin Al-Hasan Caringin Sukabumi, Sa'adat AlDarayn fí Tarjamat Tafsìr Al-Qur'ān Al- 'Azīm li Jalāluddin Al-Suyüți wa Jalāluddin AlMahalli (Jakarta: Maktabah Dar Al-Hikmah, t.th.)

${ }^{21}$ Benjamin G. Zimmer, “Al-'Arabiyyah and Basa Sunda,”50; Ajip Rosidi, Masa Depan Budaya Daerah, Kasus Bahasa dan Sejarah Sunda (Jakarta: Pustaka Jaya, 2004), 76-89.

${ }^{22}$ A. Hassan, Tafsir Al-Foerqan Tafsir Qer'an Basa Soenda (Bandung: Taman Poestaka Persatoean Islam, Januari 1929).

${ }^{23}$ Mhd. Romli dan H.N.S. Midjaja, Nurul-Bajan: Tafsir Qur'an Basa Sunda, Jilid 1 (N.V. Perboe, 1966), cet. ke-2, viii.

${ }^{24}$ Muhammad Romli, Al-Kitabul Mubin Tafsir Basa Sunda (Bandung: PT. AlMa'arif, 1991), halaman terakhir Jilid 2.

25 Anwar Musaddad dkk., Tafsir Al-Qur'an Basa Sunda, Juz 1-5 (Bandung: Proyek Penerbitan Kitab Tafsir Al-Qur'an Basa Sunda Jawa Barat dicetak CV. Angkasa, 1991), Jilid 1, cet. ke-2, vii.

${ }^{26}$ Moh. E. Hasim, Ayat Suci Lenyepaneun (Bandung: Pustaka, 1994).

${ }^{27}$ Uu Suhendar, Tafsir Al-Razi Juz 'Amma jeung Al-Fatihah, Kasaluyuan Surat, Ayat jeung Mufrodat (Tasikmalaya: Pustaka Al-Razi, 2011). 
tidak bisa dilepaskan dari kebijakan kolonial Belanda yang sejak awal abad ke19 menerapkan kebijakan politik etis pendidikan bagi kaum pribumi melalui pengajaran bahasa Sunda standar di sekolah Priangan. ${ }^{28}$ Selain itu, latar daerah penulis tafsir kiranya juga berpengaruh terhadap keragaman dialek dan kehalusan bahasanya. Umumnya bahasa yang digunakan merupakan bahasa Sunda Priangan dengan dialek daerah tertentu (Garut, Sukabumi, Bandung, Ciamis dan Tasikmalaya). Dialek Garut misalnya digunakan Mustapa dan dialek wewengkon Sukabumi tampak pada Sanusi. Sedang tafsir pasca kemerdekaan, umumnya menggunakan dialek Bandung seiring dengan pemberlakuannya sebagai bahasa lulugu (bahasa pergaulan umum masyarakat Jawa Barat) pasca kemerdekaan. ${ }^{29}$ Kiranya perlu kajian lebih lanjut sejauh mana keragaman aspek dialek bahasa Sunda ini berpengaruh terhadap penafsiran Al-Qur'an.

Sementara dilihat dari sisi metodologi tafsir, umumnya tafsir Sunda menggunakan metode analitis (tah/ihi), meski dengan pendekatan, corak dan kecenderungan ideologi yang beragam. ${ }^{30}$ Kecenderungan sufistik misalnya, tampak pada Qur'anul Adhimi karya Mustapa. Sebagaimana akan dijelaskan, tafsir ini merupakan satu-satunya tafsir dengan pendekatan sufistik yang sangat kuat. Ini berbeda dengan Sanusi yang cenderung menggunakan pendekatan tafsir bil ma'tsur dalam sejumlah tafsirnya. Karya-karya Sanusi umumnya tidak bisa lepas dari kecendrungan dirinya sebagai ulama polemis dengan latar pemikiran tradisional pesantren. Seiring dengan perkembangan arus pembaharuan Islam di Priangan awal abad ke-20, sejumlah tafsir reformis (modernis) bermunculan dengan menggunakan pendekatan bi al-ra'y, seperti tampak pada Nurul-Bajan, Alkitabul Mubin, Ayat Suci Lenyepaneun, dan AlRazi. Tafsirterakhir ini banyak dipengaruhi kecenderungan sosial kemasyarakatan (adab al-ijtima'i). Pendekatan bi al-ra'y juga tampak pada Tafsir Sunda Proyek yang cenderung didominasi kepentingan politik Orde Baru. Kiranya hanya Wiranatakusumah $\mathrm{V}$ yang memilih kecenderungan susastra Sunda dalam tafsirnya, Surat Al-Baqoroh yang berbentuk puisi

${ }^{28}$ Thamrin Gunardi dan E. Juhana Wijaya, Perkembangan Pendidikan di Jawa Barat dari Zaman ke Zaman (Bandung: Armico, 1997), 55-59.

${ }^{29}$ Wahyu Wibisana, Ngamumule Basa Sunda (Bandung: Kiblat, 2011), 13-20.

${ }^{30}$ Tentang metodologi tafsir lihat 'Abd Al-Hayy Al-Farmawi, Al-Bidāyah fi al-

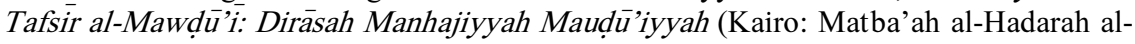
'Arabiyyah, 1977). 
dangding/guguritan. Sebuah kreatifitas literer yang kemudian diikuti oleh Hidayat Suryalaga dalam terjemah Nur Hidayah dan Nadoman Nurul Hikmah. ${ }^{31}$

Uraian di atas menunjukkan bahwa tafsir di tatar Sunda sudah lama berkembang dan terus diproduksi hingga sekarang. Beragam aksara, dialek bahasa, metode dan latar ideologis kiranya menghiasi perkembangannya. Ini mencerminkan semangat dan keseriusan orang Sunda apapun kepentingannya untuk terus mengapresiasi Al-Qur'an dan menjaga kesinambungan dialognya dengan bahasa ibunya. Meski beredar di wilayah yang terbatas, tetapi kehadirannya mempertegas kedalaman proses penyerapan nilai keagamaan ke dalam identitas budayanya. Sebuah upayanya orang Sunda dalam memahami Al-Qur'an dengan tetap berpijak pada alam pikiran budayanya.

\section{Nuansa Budaya Sunda dalam Tafsir Berbahasa Sunda}

Tafsir bisa dikatakan merupakan produk budaya yang lahir dari proses dialektika antara penafsir dengan realitas budaya di satu pihak dan dialognya dengan Al-Qur'an di pihak lain. Dalam konteks tafsir Sunda, latar budaya kiranya cukup berpengaruh terhadap penafsir dan karyanya. Meski umumnya didominasi deskripsi wacana Qur'ani, tetapi tak sedikit nuansa budaya Sunda pun turut mewarnai. Keterpengaruhannya terutama berkaitan erat dengan unsur bahasa. Sebagai ciri utama etnis, bahasa merepresentasikan budaya. Ia mengekspresikan, membentuk dan menyimbolkan realitas budaya. ${ }^{32}$ Bahasa bagi orang Sunda, menjadi media artikulasi simbol nilai budaya dan pandangan hidupnya. ${ }^{33}$ Karenanya bahasa Sunda ketika digunakan sebagai instrumen penafsiran, tidak saja mempermudah pemahaman atas Al-Qur'an,

${ }^{31}$ H.R. Hidayat Suryalaga, Nur Hidayah: Saritilawah Basa Sunda, Al-Qur'an 30 Juz Winangun Pupuh (Bandung: Yayasan Nur Hidayah, 1994) dan Nadoman Nurul Hikmah (Bandung: Yayasan Nur Hidayah, 2010).

32 Mikihiro Moriyama, Semangat Baru: Kolonialisme, Budaya Cetak dan Kesastraan Sunda Abad ke-19, terj. Suryadi (Jakarta: KPG, 2005), 13; F.X. Rahyono, Kearifan Budaya dalam Kata (Jakarta: Wedatama Widya Sastra, 2009), 77.

33 Tentang pandangan hidup orang Sunda, lihat Suwarsih Warnaen dkk., Pandangan Hidup Orang Sunda Seperti Tercermin dalam Tradisi Lisan dan Sastra Sunda (Bandung: Bagian Proyek Penelitian dan Pengkajian Kebudayaan Sunda (Sundanologi) Dirjen Kebudayaan Depdikbud, 1987); Suwarsih Warnaen dkk., Pandangan Hidup Orang Sunda Seperti Tercermin dalam Tradisi Lisan dan Sastra Sunda Penelitian Tahap II (Konsistensi dan Dinamika) (Bandung: Bagian Proyek Penelitian dan Pengkajian Kebudayaan Sunda Dirjen Kebudayaan Depdikbud, Bandung, 1987); Yus Rusyana dkk., Pandangan Hidup Orang Sunda seperti Tercermin dalam Kehidupan Dewasa ini (Tahap III) (Bandung: Bagian Proyek Penelitian dan Pengkajian Kebudayaan Sunda Dirjen Kebudayaan Depdikbud, Bandung, 1988/1989). 
menghidupkan bahasa Sunda dan memperluas fungsi sosialnya, tetapi sekaligus juga memuluskan jalan bagi masuknya pengaruh nuansa budaya Sunda dan kearifannya ke dalam karya tafsir.

Bagi penafsir Sunda, sedikitnya terdapat tiga aspek nuansa budaya Sunda yang menjadi ciri khas dalam menafsirkan Al-Qur'an ke dalam bahasa Sunda, yakni tatakrama bahasa, ungkapan tradisional Sunda, dan gambaran alam Sunda. Ketiganya menjadi indikator awal sejauh mana sebuah tafsir betulbetul nyunda atau bercitarasa Sunda. Semakin dominan ketiga aspek nuansa budaya Sunda tersebut, kiranya semakin nyunda tafsir tersebut.

\section{Tatakrama Bahasa}

Tatakrama bahasa atau undak usuk basa (tingkatan bahasa/speech levels) merupakan sistem tingkatan tutur dalam bahasa Sunda menyangkut perbedaanperbedaan yang harus digunakan dalam hal usia, kedudukan, pangkat, tingkat keakraban serta situasi di antara yang disapa dan yang menyapa, atau antara pembicara, lawan bicara, dan yang dibicarakan. ${ }^{34}$ Tatakrama bahasa semula berasal dari budaya Jawa-Mataram yang kemudian berpengaruh ke dalam bahasa Sunda. ${ }^{35}$ Ia menunjukkan kuatnya prinsip hormat dalam etika Jawa ${ }^{36}$ yang mencerminkan "budaya feodal" pada masa lalu. ${ }^{37}$ Dalam bahasa Sunda, sejak Kongres Basa Sunda tahun 1988 penggunaan undak usuk basa tidak lagi dimaksudkan sebagai pembedaan status sosial, tetapi menjadi alat untuk saling menghargai dan menghormati. Kini umumnya digunakan dua ketegori besar ragam bahasa: bahasa hormat (halus) dan loma (kurang hormat/cenderung kasar), untuk diri sendiri maupun orang lain. ${ }^{38}$

34 Undak usuk basa (undak = tahap, usuk = kayu yang biasanya digunakan sebagai penyangga atap rumah). Lihat Ajip Rosidi, "Ngabina jeung Ngamekarkeun Kabudayaan Sunda", dalam Ajip Rosidi dkk., Polémik Undak Usuk Basa Sunda (Bandung: PT. Mangle Panglipur, 1987), 19-24; Edmund A. Anderson, "Speech Levels: The Case of Sundanese," Pragmatics, 3: 2, International Pragmatics Association, n.d., 107.

35 Ayatrohaédi, "Bahasa Sunda di Daerah Cirebon," Disertasi Universitas Indonesia, 1978, 11; Suwarsih Warnaen dkk., Etika Sunda, Suatu Ikhtiar untuk Mengungkap Etika Orang Sunda dan Tatakramanya Melalui Hasil Penelitian KualitatifKuantitatif(Jakarta: Yayasan Pembangunan Jawa Barat, 1993), 165.

${ }^{36}$ Frans Magnis-Suseno, Etika Jawa (Jakarta: PT. Gramedia, 1991), 60.

${ }^{37}$ Ajip Rosidi, Kearifan Lokal dalam Perspektif Budaya Sunda, 35.

${ }^{38}$ Terdapat enam bentuk dalam kedua ragam bahasa ini, yaitu basa kasar, basa sedeng, basa lemes, basa lemes pisan, basa kasar pisan, dan basa panengah. Budi Rahayu Tamsyah, Kamus Undak Usuk Basa Sunda (Bandung: Geger Sunten, 2006), cet. ke-7, 9; Karna Yudibrata dkk., Bagbagan Makéna Basa Sunda (Bandung: Rahmat Cijulang, 1990), 46-47; Hidayat Suryalaga, "Ngungkulan Bangbaluh Ngagunakeun Undak Usuk 
Semua penafsir Sunda menggunakan tatakramabahasadalam tafsirnya, meski dengan beragam penggunaan bahasa hormat dan loma sebagaimana dijelaskan sebelumnya. Penafsir berupaya menginterpretasikan bahasa AlQur'an yang cenderung egaliter untuk disesuaikan dengan latar budayanya. Dalam tafsir Sunda, tatakrama bahasa misalnya tampak pada terjemah QS. Thaha [20]: 92-93:

Ngadawuh Nabi Musa, Hei Nabi Harun naon anu ngahalangan anjeun, waktu ningali anjeun ka Bani Israil sasar kupur kabeh. Kana hanteu nurutkeun anjeun ka kaula. Naha make nyulayaan anjeun kana parentah kaula. $^{\text {"39 }}$

Musa nyarita (ka Harun dina nalika dongkapna ti gunung Thur): "He Harun! Naon nu janten pamengan ka anjeun nalika anjeun ningali ka maranehna parantos sarasab (malusyrik)". "Bet ngantep henteu tumut kana conto kang rai (dina ambek karana Alloh sareng merangan jalmijalmi nu kupur ka Mantenna)?, atanapi memang kang raka ngahaja doraka kana parentahan kang rai?"40

Musa nyarita, "He Harun naon nu ngahalangan ka anjeun, waktu anjeun mireungeuh maranehna geus sarasab?(Nepi ka) anjeun henteu nurut ka kaula? Naha anjeun ngahaja wangkelang kana parentah kaula?"11

Musa nyarita: "Yeuh Harun, naon nu jadi halangan pikeun hidep basa hidep ngajeueung kasasar lampah? Ku naon teu nurut ka kami? Naha hidep geus ngalawan kana parentah kami?"42

Ayat tersebut berbicara tentang Nabi Musa yang menegur kakaknya, Nabi Harun, sepulangnya dari gunung Thursina. Musa marah karena kaum Bani Israil yang ditinggalkan dan dititipkan pada Harun selama 40 hari itu malah melakukan kemusyrikan dengan menyembah anak sapi. Dialog di antara kedua Nabi bersaudara itu diceritakan dalam tafsir Sunda dengan menggunakan ragam bahasa hormat (halus) meski dengan diksi yang berbeda-beda untuk O1 (kaula, kang rai, kami)dan $\mathrm{O} 2$ (anjeun, kang raka, hidep). Tatakrama bahasa ini terasa

Basa," dalam Kempelan Makalah Kongres Basa Sunda VIII, Subang 28-30 Juni 2005, 149.

${ }^{39}$ Ahmad Sanusi, Rawdhat al- 'Irfän, Jilid 2, 564.

${ }^{40}$ Mhd. Romli, Alkitabul Mubin, Jilid 2, 674-675.

${ }^{41}$ Anwar Musaddad dkk., Tafsir Al-Qur'an Basa Sunda, Jilid 4, 299.

${ }^{42}$ Moh. E. Hasim, Ayat Suci Lenyepaneun, Jilid 16, 248-250. Artinya: "Berkata Musa: 'Hai Harun, apa yang menghalangi kamu ketika kamu melihat mereka telah sesat, (sehingga) kamu tidak mengikuti Aku? Maka apakah kamu telah (sengaja) mendurhakai perintahku?" 
berbeda, misalnya ketika menggambarkan dialog Allah dengan iblis dalam QS. Al-A'raf [7]: 12:

(a) Maka mariksa Allah, naon anu nyegah ka manéh (iblis) kana heunteudaéksujudmanéh ka Nabi Adam, waktu maréntahAing ka manéh.

(b) Ngajawab iblis, ari abdi eta leuwih hade tibatan Nabi Adam karana geus ngadamelGusti ka abdi tina seuneu jeung ngadamelGusti ka Nabi Adam tina taneuh. ${ }^{43}$

Penggunaan ragam bahasa lomakurang hormat (kasar) tampak pada kata maneh (kamu), daek sujud (mau bersujud), dan marentah Aing (Aku perintahkan) (bagian a). Ketiganya diungkapkan oleh Allah sebagai orang pertama (O1). Penafsir menggunakannya untuk menunjukkan rendahnya kedudukan dan ketidakhormatannya terhadap Iblis dibanding kepada Allah. Sebaliknya, pada bagian b, ketika Iblis menjawab dan berkedudukan sebagai O1, maka ragam bahasa pun berubah menjadi ragam hormat (abdi/saya, ngadamel Gustißngkau menciptakan). Penafsir menganggap bahwa Iblis sebagai makhluk tetap harus memiliki rasa hormat terhadap Allah, meski penafsir pada dasarnya tidak menyukai Iblis. Di sini menunjukkan bahwa latar penafsir sebagai pengguna bahasa Sunda memainkan peran sangat penting dalam memilih ungkapan ragam bahasa yang tepat dalam menafsir teks ayat. Karenanya dibanding tafsir berbahasa lain yang relatif tidak mengenal tingkatan atau tatakrama bahasa, penggunaannya dalam tafsir menjadi salah satu bentuk kreatifitas lokal dalam memelihara "kearifan" budayanya.

\section{Ungkapan Tradisional Sunda}

Selain tatakrama bahasa, berbagai ungkapan tradisional Sunda (babasan [ungkapan], paribasa [peribahasa] dan kecap-kecapan) juga menjadi aspek penting dalam membentuk kekhasan tafsir Sunda. ${ }^{44}$ Ia merupakan kekayaan

43 Ahmad Sanusi, Rawḍat al-'Irfān, Jilid 1, 269-270. Artinya: "Maka Allah memeriksa, apa yang mencegah kamu iblis untuk tidak mau sujud pada Nabi Adam, ketika Aku memerintahmu. Iblis menjawab, saya lebih baik daripada Nabi Adam karena Gusti sudah menciptakan saya dari api dan Gusti menciptakan Adam dari tanah.”

${ }^{44}$ Babasan berarti ucapan tertentu yang digunakan dalam arti kiasan, biasanya merupakan kalimat tidak sempurna; Paribasa (Ind.: peribahasa) berarti ucapan tertentu, sedikit tapi tepat, berupa perumpamaan dalam menjalani kehidupan, biasanya merupakan kalimat sempurna. Kecap-kecapan adalah ucapan yang sudah tetap untuk menyampaikan perasaan dengan bahasa yang rasanya bisa menggambarkan maksud penuturnya secara tepat dan mantap. Semua diungkapkan secara estetis, mengandung unsur irama dan kekuatan bunyi. Momon Wirakusumah dan Buldan Djajawiguna, Kandaga Tata Basa 
batin budaya Sunda yang mengandung nasehat, prinsip hidup dan aturan tingkah laku. ${ }^{45}$ Bisa dikatakan, kearifan lokal orang Sundacukup banyak bersumber darinya. Umumnya penafsir Sunda menyadari pentingnya penggunaan ungkapan tradisional ini, meskipun kadar penggunaannya berbedabeda. Qur'anul Adhimi, Nurul-Bajan, Ayat Suci Lenyepaneun misalnya, cukup kaya dengan ungkapan tradisional. Tidak demikian halnya dengan Rawdat Al'Irfan, Malja' Al-Talibin, Alkitabul Mubin, Tafsir Al-Qur'an Basa Sunda Proyek,Al-Razi dan lainnya. Penggunaannya dalam tafsir Sunda tidak saja memperkuat makna agar mudah dipahami dan meresap ke dalam hati (keuna kana hate), ${ }^{46}$ tetapi juga membuat ungkapan tradisional tersebut cenderung lebih bermakna Islami karena diselaraskan dengan nilai ajaran Islam. ${ }^{47}$

Sebagai contoh, di sini disebutkan penjelasan tafsir Ayat Suci Lenyepaneun karya Moh. E. Hasim ${ }^{48}$ tentang "penyakit hati" yang dimiliki orang munafik dalam QS. Al-Baqarah [2]: 10:

Panyakit nu ngancik dina ati téh mimitina mah mencenit leutik siga pisirungeun dina tunggul, lila-lila ngagedéan, asa mokaha mirucaan ceceremed mipit teu amit ngala teu ménta, lila-lila jadi ngabaju, beuki dieu beuki ludeung nepi ka ahirna lébér wawanén jadi bangsa gerot. Waktu masih jadi bawahan geus mirucaan daek nampa suap jeung ngajilat malar naék pangkat, lila-lila suap jeung pungli jadi ngadaki, ari geus jadi patinggi mah ningkat kawani, teu kapalang belang pindah pileumpangan sakalian jadi koruptor kelas kakap. Sirikpidik ka nu leutik, belangbayah ka sasama jeung sawenang-wenang ka cacah kuricakan geus teu aya nu dipantrang. Gedé hulu siga jojodog unggah ka salu jeung kadedemes kawas nu kokoro manggih mulud puasa manggih lebaran. Galak jeung campelak sahaok kadua gaplok, tapi ana patepung jeung nu

Sunda (Bandung: Ganaco, 1957), 58; Abdurrachman dkk., Ungkapan Tradisional Daerah Jawa Barat (Jakarta: Depdikbud Proyek Inventarisasi dan Dokumentasi Kebudayaan Daerah, 1984); Panitia Kamus Lembaga Basa \& Sastra Sunda (LBSS), Kamus Umum Basa Sunda (Bandung: Tarate, 1985), xiii dan 43-44.

${ }^{45}$ Ajip Rosidi, Babasan \& Paribasa: Kabeungharan Basa Sunda, Jilid I (Bandung: Kiblat Buku Utama, 2005), 6-7.

${ }^{46}$ Mikihiro Moriyama, "Bahasa Sunda dan Islam: Suatu Potret 2010," Makalah Workshop Internasional Islam dan Kedaerahan di Jawa Barat: Potret 2010, UIN Bandung-Monash University, 14 Oktober 2010, 6.

47 Ajip Rosidi, "Pandangan Hidup Orang Sunda Seperti Nampak dalam Peribahasa”, dalam Cik Hasan Bisri dkk., Pergumulan Islam dengan Kebudayaan Lokal di Tatar Sunda (Bandung: Kaki Langit, 2005), 4-8.

${ }^{48}$ Tentang karakteristik penafsiran Hasim, lihat Jaja Zarkasyi, "Bahasa Sunda dalam Penafsiran Al-Qur'an,” Tesis, SPs UIN Syarif Hidayatullah Jakarta, 2009. 
jangkung gedé, nu kumisna baplang godégna ngejejembrung, poyongkod baé siga teu daya teu upaya, batan ngalawan mah kalah $\mathrm{ka}$ serahbongkokan. ${ }^{49}$

Kalimat yang ditebalkan tersebut merupakan ungkapan tradisional berupa babasan, peribahasa dan kecap-kecapan yang mencerminkan sifat dan perilaku buruk orang munafik. Beberapa di antaranya menggunakan kalimat kiasan dan perumpamaan berupa nasehat atau sindiran sebagai bagian dari kearifan lokal. Misalnya ungkapan kadedemes kawas kokoro manggih Mulud, puasa manggih lebaran berarti rakus karena merasa mumpung mendapat rejeki/makanan. ${ }^{50}$ Ungkapan tersebut menggunakan perumpamaan perilaku orang miskin ketika datangnya bulan Mulud atau perilaku orang Islam selepas puasa saat hari lebaran. Entah sejak kapan ungkapan itu digunakan. Tetapi ia merupakan sindiran bahwa tidak baik terlalu berlebihan saat mendapat banyak makanan.

Ungkapan tradisional lainnya, pedot jodo panjang duriat (putus jodoh panjang rasa cinta) misalnya digunakan untuk memperkuat makna kasih sayang dalam Al-Qur'an (al-marhamah). Mustapa misalnya menyebutkannya ketika menafsirkan QS. Al-Balad [90]: 10-20:

Mipir bukit palasari, tanjakan maraga cinta. Sundana: apik ka ati nyaah ka tanaga, udaran cangreud tina beuheung, tina cangreud loba biheung. Jeung sasama silih papatahan silih pikaheman. Nu matak sok pedotjodopanjangduriat, jodo meunang jodo, jadi opat modalna kasukaan, jadi kalimana. ${ }^{51}$

\footnotetext{
${ }^{49}$ Moh. E. Hasim, Ayat Suci Lenyepaneun, Jilid 1, 36-37. Artinya: Penyakit hati itu mulanya kecil layaknya tunas pohon, semakin lama semakin membesar, makin menjadi, makin mengganggu, mulanya mencuri, lalu terbiasa, makin berani hingga akhirnya menjadi raja pencuri. Ketika masih menjadi bawahan sudah coba-coba menerima suap dan menjilat agar naik jabatan, semakin lama suap dan pungli menjadi kebiasaan. Ketika menjadi pejabat meningkat pula keberanian, tidak tanggung-tanggung pindah arah hidup sekalian saja menjadi koruptor kelas kakap. Iri pada orang kecil, munafik pada sesama dan sewenang-wenang pada rakyat kecil, semua tidak dipantang. Sombong, rakus, pemarah. Tetapi ketika bertemu orang tinggi besar, berkumis, berjambang, maka ia pun menciut tiada daya, daripada melawan malah menyerah saja.

${ }^{50}$ Ajip Rosidi, Babasan \& Paribasa, 100; Panitia Kamus Lembaga Basa \& Sastra Sunda (LBSS), Kamus Umum Basa Sunda, 242.

51 Ajip Rosidi, Haji Hasan Mustapa, 422. Artinya: Mendaki bukit Palasari, tanjakan Margacinta. Artinya (ayat itu), meraba hati menghemat tenaga, lepas ikatan di leher, karena dalam ikatan itu banyak kemungkinan. Dengan sesama saling menasehati, saling menyayangi. Karenanya ketika putus jodoh, tetapi tetap panjang persaudaraan, jodoh ketemu jodoh, jadi empat modal rasa suka dan pepatah ini yang kelimanya.
} 
Kata 'aqabah (tanjakan) merupakan inti ayat ini, yakni bahwa untuk menempuh jalan kebaikan tidak mudah. ${ }^{52}$ Terdapat beberapa jalan mendaki dalam mencapai kebaikan. Salah satunya menasehati dengan penuh kesabaran dan kasih-sayang. Mustapa mengatakan, "Jeung sasama silih papatahan silih pikaheman. $\mathrm{Nu}$ matak sok pedot jodo panjang duriat, jodo meunang jodo."Ungkapan tersebut merupakan komentar singkatnya atas kalimat watawăsau bi al-marhamah (ayat 17). Mustapa menekankan arti "saling menyayangi" dengan menggunakan ungkapan bahwa siapapun yang putus tak berjodoh (bercerai), hendaknya tetap saling menyayangi. Ia menarik proposisi kearifan lokal Sunda tentang kerukunan ke dalam ajaran Al-Qur'an.

\section{Gambaran Alam Kesundaan}

Aspek terakhir dari kekhasan tafsir Sunda berkaitan dengan gambaran alam kesundaan. Ia tidak sekedar berupa deskripsi lingkungan alam tropis tanah Pasundan dengan segala suasananya, tetapi juga boleh jadi berupa metafor flora dan fauna alam Sunda yang digunakan penafsir untuk menjangkau kedalaman rasa dan pikiran pembacanya. Tidak semua tafsir Sunda berani menggunakannya. Umumnya penjelasan ayat tidak beranjak dari wacana Qur'ani. Dibanding tafsir lainnya, Qur'anul Adhimi dan Ayat Suci Lenyepaneun kiranya cukup kaya akan gambaran alam kesundaan ini.

Tafsir Quranul Adhimi karya Haji Hasan Mustapa misalnya, menggunakan metafor alam kesundaan seperti susukan (sungai) ketika menjelaskan Surah Al-Baqarah [2]: 256: lā ikrāh fí al-dìn. "Taya paksa dina agama. Asalna ogé susukan palid sorangan, laku lampah asalna suka sorangan, nu matak ditotondénan dina sagala lampahing lampah agama, maké basa lillahi ta'ala, hartina lampah sukana sorangan, lain hayang diburuhan." ${ }^{3}$

Ungkapan susukan palid sorangan merupakan metafor untuk menggambarkan ketulusan beragama yang tanpa paksaan. Baginya beragama harus disertai kesadaran yang muncul dari perasaannya sendiri. Ibarat aliran sungai yang asalnya sejak dahulu mengalir sendiri, tanpa diatur untuk dialirkan

52 Ahmad Musthafa Al-Maraghi, Tafsìr Al-Marāghì, Juz 3 (Al-Maktabah AlShāmilah), 148.

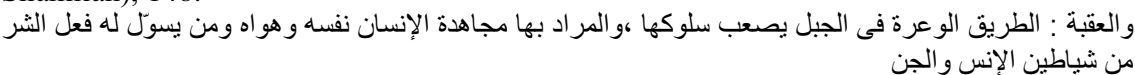

${ }^{53}$ Haji Hasan Mustapa, Adji Wiwitan, 10; Ajip Rosidi, Haji Hasan Mustapa, 399. Artinya: Tidak ada paksaan dalam agama. Sungai asalnya juga mengalir sendiri, asal perbuatan juga karena dorongan sendiri, karenanya diberikan peringatan dalam semua amalan agama, (untuk) menggunakan bahasa lillāh ta’ālá, artinya berbuat karena dorongan diri sendiri, bukan ingin dapat upah. 
seperti sekarang (irigasi). Beragamalah sebagaimana aliran sungai itu. Itulah makna beragama karena Allah (lillāh ta'ālā), tanpa pamrih, bukan karena ingin mendapat upah.

Metafor lainnya adalah cau (pisang)ketika menafsirkan Surah AnNahl/16: 98, Mustapa menggambarkan bahwa mengkaji Al-Qur'an tidak sekedar mengeja dan membacanya saja, tetapi harus sampai ke jantungnya.

Faidzā qara'ta al-Qur'ān fasta'id billāh... "Kakara hatam qulhuna, kakarana hatam Qur'anna, lain ku éjah tarabas, masih tepi ka ngarasa, teu nyaho mana kararas, kararasa ku maranéhna, lain ngaguru ka jantung, ngeunah ka jantung, ngeunah cauna sotéh geus moréat turuyan sikatan. Owérna mah kakuwar-kowér, kararasna karasa badan asa pasiksak; kajeun da geus dipulangkeun, enggeus heubeul diinjeumkeun wisaya pulang ka purba." 54

Mustapa menyebutkan bahwa khatam Al-Qur'an itu bukan sekedar mereka bacaan, tapi harus sampai di rasa. Jangan sampai tak tahu mana kararas (daun pisang yang menua dan kering). Metafor pembacaan mendalam dan tuntas yang memerlukan waktu lama untuk sampai ke ujungnya. "Coba pula berguru pada jantung pisang," kata Mustapa. Metafor proses belajar secara bertahap ke arah kemajuan. Ibarat jantung pisang yang semakin lama semakin bergeser dengan pisang yang bertambah besar dan membuahkan hasil. Mustapa menyadari, meskipun badan terasa sakit ibarat kararas yang menggantung dan terombang-ambing ke sana-ke mari, namun itu semua sudah dibalas dengan kenikmatan. Sebuah metafor cantik untuk menggambarkan pentingnya proses belajar secara matang dengan meminjam metafor alam kesundaan.

Sebuah metafor yang memperkaya horizon penafsiran yang disenyawakan dengan suasana alam Sunda. Ia mencoba menempatkan tafsir dalam lingkungan alam budaya Sunda. Sebuah alam yang ditemuinya dengan kekayaan flora dan fauna di tengah alam yang subur. Masa kecil Mustapa dihabiskan di alam pegunungan Cikajang dengan hutan, kebun, aliran sungai dan kolam. Alam Sunda yang dalam bahasa Wittfogel (1936) disebut sebagai

\footnotetext{
${ }^{54}$ Haji Hasan Mustapa, Adji Wiwitan, 18-19; Ajip Rosidi, Haji Hasan Mustapa, hlm, 406-407. Artinya: Barusan saja khatam qulhu-nya. Barusan saja khatam Al-Qur'annya. Bukan mengeja dibaca langsung. Sekalipun sampai bisa merasa, tetapi tidak tahu makna kararas (daun pisang yang kering). Karasa-karasa (tahu-tahu terasa) oleh mereka juga. Coba saja berguru ke jantung (pisang). Enak pisangnya itu ketika sudah moréat (tampak) turuy dan sikat-nya (sejumlah pisang). Ujung daun pisang itu terombangambing. Kararas-nya terasa badan agak sakit. Biar saja, kan sudah dikembalikan. Setelah lama dipinjamkan rasa sakit, kembali ke Yang Kuasa.
} 
tempat tinggal hydrolic society, sehingga kerap menjadikan "air" (cai, ci) sebagai nama tempat. ${ }^{55}$ Karena kesuburannya itu pula, Brouwer, seorang rohaniwan Katolik, menyebut tatar Sunda terjadi ketika Tuhan tersenyum. ${ }^{56}$

Demikian beberapa aspek dari nuansa budaya Sunda yang berpengaruh dan digunakan penafsir Sunda dalam tafsirnya. Tentu saja masih banyak aspek lain dari kekayaan bahasa dan sastra Sunda yang bisa digunakan dalam memperkaya nuansa budaya Sunda dalam penafsiran. Misalnya bahasa kirata, dangding/guguritan, wawangsalan, carita pantun, dongeng, mantra dan lainnya. Semua tergantung kepada kemauan dan kemampuan penafsir dalam menyelaraskan kekayaan bahasa dan sastra Sunda ke dalam penafsiran.

Penggunaan berbagai aspek nuansa budaya Sunda dalam tafsir merupakan bentuk kreatifitas lokal dalam khazanah tafsir Nusantara. Ia mencerminkan sejauh mana nilai ajaran Al-Qur'an diserap dan didialogkan ke dalam identitas budaya Islam Sunda. Tidak ada dikotomi agama dan budaya di sini sebagaimana diasumsikan Wessing. ${ }^{57}$ Sebuah identitas budaya Islam lokal yang tidak bisa lagi dianggap pinggiran. Tradisi pengkajian Al-Qur'an di tatar Sunda semakin meneguhkan identitas Islam lokal yang terhubung dengan jaringan intelektual Islam Nusantara. ${ }^{58}$

\section{Penutup}

Tafsir Sunda tidak bisa diabaikan dalam diskursus kajian Al-Qur'an di Nusantara. Signifikansinya tidak hanya terletak pada kesinambungan jaringan tradisi keilmuan Islam Nusantara, tetapi juga dalam kreatifitas lokal tafsir yang lahir dari kearifan bahasa dan latar budaya. Kehadirannya tidak saja berkontribusi dalam menghidupkan bahasa Sunda, tetapi juga mempertegas pengaruh latar budaya dalam proses indigenisasi Islam di tatar Sunda. Tatakrama bahasa, ungkapan tradisional dan gambaran alam kesundaan merupakan sebagian dari upaya orang Sunda dalam memahami Al-Qur'an melalui kekayaan latar budayanya. Terjadi pertemuan antara prinsip dan nilai 1986), 87.

55 Haryoto Kunto, Semerbak Bunga di Bandung Raya (Bandung: Granesia,

56 M.A.W. Brouwer, Perjalanan Spiritual dari Gumujeng Sunda, Eksistensi Tuhan, sampai Siberia (Jakarta: KPG, 2003), 1.

57 Robert Wessing, "Cosmology and Social Behavior in A West Javanese Settlement, "Disertasi, the University of Illinois at Urbana-Champaign, 1974, 286.

58 Azyumardi Azra, The Origins of Islamic Reformism in Southeast Asia: Networks of Malay-Indonesian and Middle Eastern 'Ulama' in the seventeenth and eighteenth centuries (Honolulu: ASAA-Allen \& Unwin and University of Hawai'i Press, 2004). 
budaya Sunda dengan ajaran Al-Qur'an. Semua diadaptasikan dalam kerangka ajaran Al-Qur'an yang dijejakkan dalam bingkai budaya masyarakatnya. Sebuah upaya indigenisasi Islam dan peneguhan identitas Islam lokal yang tidak terjebak pada aspek formalitas-simbolik dibanding jiwa kesundaan. Baginya, identitas Islam sejatinya tetap berpijak pada kekayaan bahasa dan budaya masyarakatnya. Sebuah pendekatan bernuansa etnis dalam memahami AlQur'an sebagai bagian dari pengukuhan identitas Islam lokal itu dalam bingkai warisan peradaban Islam Nusantara.

\section{Daftar Pustaka}

'Abdullah bin Al-Hasan Caringin Sukabumi, Muhammad. Sa'ādat Al-Darayn fī Tarjamat Tafsìir Al-Qur'ān Al-'Azhìm li Jalāluddìn Al-Suyūthì wa Jalāluddìn Al-Mahalli. Jakarta: Maktabah Dar Al-Hikmah, t.th.

Abdurrachman dkk. Ungkapan Tradisional Daerah Jawa Barat Jakarta: Depdikbud Proyek Inventarisasi dan Dokumentasi Kebudayaan Daerah, 1984.

Anderson, Edmund A. "Speech Levels: The Case of Sundanese" Pragmatics, 3: 2, International Pragmatics Association, n.d.

Ayatrohaédi."Bahasa Sunda di Daerah Cirebon.”DisertasiUniversitas Indonesia, 1978.

Azra, Azyumardi. The Origins of Islamic Reformism in Southeast Asia: Networks of Malay-Indonesian and Middle Eastern 'Ulama' in the seventeenth and eighteenth centuries. Honolulu: ASAA-Allen \& Unwin and University of Hawai'i Press, 2004.

Brouwer, M.A.W. Perjalanan Spiritual dari Gumujeng Sunda, Eksistensi Tuhan, sampai Siberia. Jakarta: KPG, 2003.

—. "Sejarah Masuknya Islam ke Tatar Sunda dan Perkembangannya." Dalam Perhimpunan KB PII, Ngamumule Budaya Sunda Nanjeurkeun Komara Agama.Bandung: Perhimpunan KB PII, 2006.

Ekadjati, Edi S., dan Undang A. Darsa.Katalog Induk Naskah-Naskah Nusantara: Jawa Barat; Koleksi Lima Lembaga. Jakarta: YOI dan EFEO, 1999.

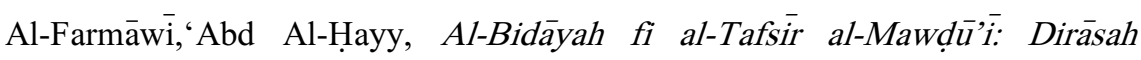
Manhajiyyah Mauḍu'iyyah.Kairo: Matba'ah al-Hadarah al-‘Arabiyyah, 1977. 
Gunardi, Thamrin dan E. Juhana Wijaya.Perkembangan Pendidikan di Jawa Barat dari Zaman ke Zaman.Bandung: Armico, 1997.

Hafiduddin, Didin. "Tafsir al-Munir Karya Imam Muhammad Nawawi Tanara." Dalam Ahmad Rifa'i Hasan (ed.). Warisan Intelektual Islam Indonesia. Bandung: Mizan, 1992.

Hasim, Moh. E. Ayat Suci Lenyepaneun. Bandung: Pustaka, 1994.

Hassan, A. Tafsir Al-Foerqan Tafsir Qer'an Basa Soenda. Bandung: Taman Poestaka Persatoean Islam, Januari 1929.

Iskandar, Mohammad.Para Pengemban Amanah, Pergulatan Pemikiran Kiai dan Ulama di Jawa Barat 1900-1950.Yogyakarta: Mata Bangsa, 2001.

Johns, A.H. "She desired him and he desired her" (Qur'an 12:24): 'Abd al-Ra'úf's treatment of an episode of the Joseph story in Tarjumānal-Mustafid." Archipel. Volume 57, 1999.

_. "Penerjemahan" Bahasa Arab ke dalam Bahasa Melayu: Sebuah Renungan."Dalam Henri Chambert-Loir (peny.).Sadur Sejarah Terjemahan di Indonesia dan Malaysia. Jakarta: KPG, 2009.

Koentjaraningrat.Pengantar Ilmu Antropologi.Jakarta: Rineka Cipta, 1990, cet. ke-8.

Kebudayaan, Mentalitas dan Pembangunan.Jakarta: Gramedia Pustaka Utama, 2004.

Kunto, Haryoto.Semerbak Bunga di Bandung Raya. Bandung: PT. Granesia, 1986.

Magnis-Suseno, Frans.Etika Jawa.Jakarta: PT. Gramedia, 1991.

Makki, Ahmad bin Abdullah Mahfudz. Tarjamah Tafsìir Al-Qur'ān Al-'Azìn li Jalāluddīn Al-Suyūt $\bar{i}$ wa Jalāluddìn Al-Mahalli.jJilid 1, Sukabumi: Percetakan Al-Salafiyah, tt.

Manshur, Fadlil Munawar."Rawdhatul 'Irfān fì Ma'rifatil Qur'ān Karya Kiai Haji Ahmad Sanusi: Analisis Semiotik dan Resepsi." Tesis PPs UGM Yogyakarta, 1992.

Al-Maraghi, Ahmad Musthafa, Tafsìi Al-Marāghì, Juz 3. Al-Maktabah AlShāmilah.

Moriyama, Mikihiro.Semangat Baru: Kolonialisme, Budaya Cetak dan Kesastraan Sunda Abad ke-19.Terj. Suryadi, Jakarta: KPG, 2005.

_. "Bahasa Sunda dan Islam: Suatu Potret 2010." Makalah Workshop Internasional Islam dan Kedaerahan di Jawa Barat: Potret 2010, UIN Bandung-Monash University, 14 Oktober 2010.

Muhsin, Imam."Tafsir Al-Qur'an dan Budaya Lokal.”DisertasiUIN Sunan Kalijaga, 2008. 
Musaddad,Anwar, dkk. Tafsir Al-Qur'an Basa Sunda. Bandung: Proyek Penerbitan Kitab Tafsir Al-Qur'an Basa Sunda Jawa Barat dicetak CV. Angkasa, 1991.

Mustapa, Haji Hasan.Aji Wiwitan Qur'an Sutji, kenging ngumpulkeun Wangsaatmadja. Bandung 7 Juli 1920.

-Petikan Qoer'an Katoet Adab Padikana, diurus djeung diatur ku Comite Mendakna. Bandung: Droek Boehron Bd., 1937.

Noorduyn, J., dan A. Teeuw.Tiga Pesona Sunda Kuna, terj. Hawe Setiawan. Jakarta: Pustaka Jaya, 2009.

Nurtawab, Ervan.Tafsir Al-Qur'an Nusantara Tempo Doeloe. Jakarta: Ushul Press, 2009.

Oyon OS. "Islam Nyunda \& Sunda Ngislam." Dalam Wahyu Wibisana dkk. Salumar Sastra.Bandung: Geger Sunten, 1997, cet. ke-2.

Panitia Kamus Lembaga Basa \& Sastra Sunda (LBSS).Kamus Umum Basa Sunda.Bandung: Tarate, 1985.

Rahyono, F.X. Kearifan Budaya dalam Kata. Jakarta: Wedatama Widya Sastra, 2009.

Rohmana, Jajang A. “Kajian Al-Qur'an di Tatar Sunda: Sebuah Penelusuran Awal." Jurnal Suhuf, Vol. 6, No. 1, 2013, 197-224.

Romli, Mhd., \& H.N.S. Midjaja.Nurul-Bajan: Tafsir Qur'an Basa Sunda. N.V. Perboe, 1966, cet. ke-2.

Romli, Muhammad.Al-Kitabul Mubin Tafsir Basa Sunda. Bandung: PT. AlMa'arif, 1991.

Rosidi, Ajip.Haji Hasan Mustapa jeung Karya-karyana. Bandung: Pustaka, 1989.

------ (ed.).Ensiklopedi Sunda, Alam, Budaya, dan Manusia. Jakarta: Pustaka Jaya, 2003.

_. Babasan \& Paribasa: Kabeungharan Basa Sunda.Jilid I Bandung: Kiblat Buku Utama, 2005.

_. "Pandangan Hidup Orang Sunda Seperti Nampak dalam Peribahasa." Dalam Cik Hasan Bisri dkk. Pergumulan Islam dengan Kebudayaan Lokal di Tatar Sunda.Bandung: Kaki Langit, 2005.

—. "Ngabina jeung Ngamekarkeun Kabudayaan Sunda." Dalam Ajip Rosidi dkk. Polémik Undak Usuk Basa Sunda.Bandung: PT. Mangle Panglipur, 1987.

- Kearifan Lokal dalam Perspektif Budaya Sunda.Bandung: Kiblat, 2011. Rusyana, Yus dkk. Pandangan Hidup Orang Sunda seperti Tercermin dalam Kehidupan Dewasa ini (Tahap III).Bandung: Bagian Proyek Penelitian 
dan Pengkajian Kebudayaan Sunda Dirjen Kebudayaan Depdikbud, Bandung, 1988/1989.

Saenong, Farid F. "Vernacularization of the Qur'an: Tantangan dan Prospek Tafsir Al-Qur'an di Indonesia." Interview dengan Prof. A.H. Johns, Jurnal Studi Al-Qur'an, Vol. 1, No. 3, 2006.

Sanusi, Ahmad.Malja' al-Ṭălibìn fī Tafsìir Kalām Rabb al-'Ālamīn, (Pangadjaran Basa Soenda). Batavia Centrum, Kantor Cetak Al-Ittihad, 1931/1349 H.

_.Rawḍt al-'Irfān fī Ma'rifat al-Qur'ān. Sukabumi: Pesantrén Gunung Puyuh, t.th.

-Tamsjijjatoel-Moeslimien Fie Tafsieri Kalami Rabbil'Alamien.Sukabumi: Druk Al-Ittihad, 1931.

Schneider, Irene. "Legal and Ethno-Religious." Dalam Richard C. Martin.Encyclopaedia of Islam and the Muslim World.Vol. 2.New York: Macmillan, 2004.

Suhendar, Uu.Tafsir Al-Razi Juz 'Amma jeung Al-Fatihah, Kasaluyuan Surat, Ayat jeung Mufrodat.Tasikmalaya: Pustaka Al-Razi, 2011.

Suryalaga, H.R. Hidayat.Nur Hidayah: Saritilawah Basa Sunda, Al-Qur'an 30 Juz Winangun Pupuh.Bandung: Yayasan Nur Hidayah, 1994.

—. "Ngungkulan Bangbaluh Ngagunakeun Undak Usuk Basa." Dalam Kempelan Makalah Kongres Basa Sunda VIII, Subang 28-30 Juni 2005.

-.Nadoman Nurul Hikmah.Bandung: Yayasan Nur Hidayah, 2010.

Tamsyah, Budi Rahayu.Kamus Undak Usuk Basa Sunda.Bandung: Geger Sunten, 2006, cet. ke-7.

Warnaen, Suwarsih, dkk. Pandangan Hidup Orang Sunda Seperti Tercermin dalam Tradisi Lisan dan Sastra Sunda. Bandung: Bagian Proyek Penelitian dan Pengkajian Kebudayaan Sunda (Sundanologi) Dirjen Kebudayaan Depdikbud, 1987.

_.Pandangan Hidup Orang Sunda Seperti Tercermin dalam Tradisi Lisan dan Sastra Sunda Penelitian Tahap II (Konsistensi dan Dinamika).Bandung: Bagian Proyek Penelitian dan Pengkajian Kebudayaan Sunda Dirjen Kebudayaan Depdikbud, Bandung, 1987.

—.Etika Sunda, Suatu Ikhtiar untuk Mengungkap Etika Orang Sunda dan Tatakramanya Melalui Hasil Penelitian Kualitatif-KuantitatifJakarta: Yayasan Pembangunan Jawa Barat, 1993.

Wessing, Robert "Cosmology and Social Behavior in A West Javanese Settlement." Disertasi, the University of Illinois at Urbana-Champaign, 1974.

98 Vol. 3, No. 1, (2014) 
Memahami al-Qur'an dengan Kearifan Lokal: Nuansa Budaya Sunda dalam Tafsir al-Qur'an berbahasa Sunda.

Wibisana, Wahyu.Ngamumule Basa Sunda.Bandung: Kiblat, 2011.

Wirakusumah, Momon dan Buldan Djajawiguna.Kandaga Tata Basa Sunda.Bandung: Ganaco, 1957.

Yudibrata, Karna, dkk. Bagbagan Makéna Basa Sunda.Bandung: Rahmat Cijulang, 1990.

Zarkasyi, Jaja."Bahasa Sunda dalam Penafsiran Al-Qur'an." Tesis SPs UIN Syarif Hidayatullah Jakarta, 2009.

Zimmer, Benjamin G. "Al-'Arabiyyah and Basa Sunda: Ideologies of Translation and Interpretation among the Muslims of West Java." Studia Islamika, 7 (3): 2000: 31-65. 